\title{
Competitive rapid microwave-assisted biogenic synthesis of spherical silver nanoparticles using an aqueous leaf extract of Lepidagathis cristata: Characterization and antimicrobial studies
}

\author{
S. Himagirish Kumar, Cheera Prasad, K. Deepa, K. Sreenivasulu, N.V.V. Jyothi* \\ Department of Inorganic \& Material Chemistry, Sri Venkateswara University (NACC-A+), Tirupati, 517 502, Andhra Pradesh, India.
}

\begin{tabular}{l}
\hline ARTICLE INFO \\
\hline Article history: \\
Received on: 07/03/2018 \\
Accepted on: 07/05/2018 \\
Available online: $29 / 06 / 2018$
\end{tabular}

\section{Key words:}

Silver nanoparticles,

Lepidagathis cristata,

Extraction, Eco-friendly,

Antibacterial activity.

\begin{tabular}{l}
\hline ABSTRACT \\
\hline In the present study, microwave assisted biogenic synthesis of silver nanoparticles (Ag NPs) was carried out by \\
using aqueous leaf extract of Lepidagathis cristata ( L. cristata) which can act itself as a reducing and capping agent. \\
This method was very precious due to their economic and eco-friendly benefits. The microwave assisted biogenic \\
synthesized Ag NPs were characterized and analyzed by various instruments such as ultraviolet-visible spectroscopy \\
(UV-vis), fourier transform infrared spectroscopy (FT-IR), powder X-ray diffraction (XRD), transmission electron \\
microscopy (TEM) and scanning electron microscopy (SEM) coupled with X-ray energy dispersive spectroscopy \\
(EDS). The UV-vis absorption spectrum peak at $430 \mathrm{~nm}$, corresponds to the characteristic peak of Ag NPs. The \\
functional biomolecules present in the $L$. cristata were identified by FT-IR spectroscopy, the XRD analysis explored \\
that the synthesized Ag NPs have high crystallinity, face-centered cubic structure, and spherical shape. Ag NPs \\
properties like size and stability (Zeta potential) of the NPs were calculated by Nano Particle Size Analyzer (NPSA). \\
Further, we evaluated the antibacterial activity of the Ag NPs. The microwave assisted biogenic synthesized Ag NPs to \\
show an excellent antibacterial activity against bacteria's like Escherichia coli, Pseudomonas aeruginosa (Gram -Ve \\
bacteria), Streptococcus pneumonia (gram + Ve bacteria) and the zone of inhibition range was determined.
\end{tabular}

\section{INTRODUCTION}

Nanochemistry was one of the mainly optimistic research areas in the modern science and technology. Nanoparticles (NPs) synthesis can exhibit new and improved properties based on morphology and sizes of particles. The properties of NPs were strongly depended on the size, shape and surface nature (Xu et al., 2013; Jose et al., 2016; Vidya et al., 2016). Synthesized NPs have extensive properties in catalysis (Muthu et al., 2017), optical device (Galletto et al., 1999), electrochemical analysis (Welch et al., 2006), electronic (Daniel et al., 2004), photonics (Maier et al., 2001), information storage (Sun et al., 2000), biosensing (Han et al., 2001; West et al., 2003), biolabeling (Nicewarner-pena et al., 2001), and biomedical materials (Mirkin et al., 1996). Among the various noble metals AgNPs have been widely studied due to broad

"Corresponding Author

N.V.V. Jyothi, Department of Chemistry, S.V.U College of Sciences, S.V.

University, Tirupati - 517 502, A.P., India.

E-mail:nvvjyothi01@gmail.com application in the fields of physics, chemistry, materials science, optoelectronics, renewable energies, environmental remediation, biomedical, high antimicrobial and catalytical nature (Ahmed et al., 2015; Lopez-Esparza et al., 2016; Ruiz-Baltazar et al., 2017; Saha et al., 2017). There are several approaches in synthesis of the silver at nanoscale level such as electrochemical (Huya et al., 2017; Gulnaz et al., 2015), polyol process (Fereshteh et al., 2016; Han et al., 2017; Ammosova et al., 2017), sonochemical (Victor et al., 2017; Hao et al., 2017; Suchomel et al., 2016), chemical vapor deposion method (Brunon et al., 2017), photochemical (Kim et al., 2015; Gabriel et al., 2017), physical and chemical approaches (Abou El-Nour et al., 2010), microorganisms (Otari et al., 2014) and plant extract. The physical method involves the use of costly equipment, operates at high temperatures and occupies huge space for its set up of equipment. The chemical method involves the use of toxic chemicals which are harmful to the environment, and also to the person handling it. Biogenic synthesis in recent years by the use of plant aqueous extracts for the manufacture of NPs was an easy 
and expedient substitute to chemical and physical methods. Hence the biogenic synthesis was more suitable than other methods. In recent years the use of plant extracts (leaf, root, seed, root, flowers, bark, fruit peel, callus, and stem) for the preparation of NPs an easy, short time, inexpensive, stable, low temperature, low risk of contamination, readily available in natural sources and intensive labor. So it is convenient to other alternative methods. Plant extracts have polyphenols, alkaloids, flavonoids, proteins, enzymes, and sugars. The biomolecules act as reducing and stabilizing agents during NPs synthesis. However, the usage of plant extracts was more advantageous than other biological processes as it prevents the risk as well as the complicated process of maintaining cell cultures and the reaction time decreases from days to hours (Shankar et al., 2004; Kumar et al., 2009). domestic microwave assisted biogenic synthesis was superior merits, then traditional methods, it was controlled temperature very quickly, a very rapid method with high yields, and enhanced the stability, shape, and morphology of NPs. Major research studies reported that microwave assigned biogenic synthesis was very advanced over another alternative method for the synthesis of NPs (Nadagouda et al., 2011; Jiang et al., 2006). Although NPs synthesis using plant extracts has previously been reported in various plants such as Pongamia pinnata (Rajeshkumar, 2016), Capsicum frutescence (Sankar et al., 2017), Polygonum hydropiper (Bonnia et al., 2016), Heterotheca inuloides (MoralesLuckie et al., 2016), Candida albicans (Bhat et al., 2015), Sesbania grandiflora (Ajitha et al., 2016), Carica papaya (Banala et al., 2015), Moringa oleifera (Prasad et al., 2017), Pisum sativum peels (Prasad et al., 2017), pomegranate leaves (Prasad et al., 2017), Bottle gourds (Prasad et al., 2017), Murrayakoenigii (Prasad et al., 2017), there was still a lot of attention paid to this field because of the variety and the high probable of plants in producing NPs with different shape and size. Silver nanoparticles (Ag NPs) have fascinated the awareness of numerous researchers compelling in the field due to its broad applications.

A survey of literature has shown that no report on the biogenic synthesis of Ag NPs using aqueous leaf extract of L. cristata. In the present work, we report for the first time the synthesis of Ag NPs by via aqueous leaf extract of $L$. cristata via biogenic synthesis. L. cristata as a common perennial herb which was located in tirumala and Talakona hills at A.P., India. $L$. cristata (family: Acanthaceae) local name in Telugu language was Mullabanthi, the whole plant body has been used as a traditional medicine. It was used in the treatment of fever, inflammations, skin itch, burns, wounds and antifungal. Leaf extract was also used in cleaning the cattle in rainy season. Recent research on $L$. cristata extracts showed the presence of alkaloids, glycosides, oleic acid which supports to the therapeutic effects believed in traditional medicine (Reddy et al., 2013; Ravikanth et al., 2001; Abudacker et al., 2014; Purma et al., 2013; Teeguarden et al., 2007). Leaf extract of $L$. cristata having bio molecules can act as reducing and capping agent and are responsible for the synthesis of Ag NPs. The synthesized Ag NPs was conformed by UV-vis, FT-IR, TEM, SEM, XRD and NPSA analysis and also studied the antibacterial activity.

\section{MATERIALS AND METHODS}

\section{Reagents and apparatus}

Silver nitrate $\left(\mathrm{AgNO}_{3}\right)$ was purchased from Sigma
Aldrich. Aqueous leaf extract of L. cristata was collected from Talakona forest located in A.P., India. Bacterial culture, the standard drug was acquired from S.D Fine chemicals and domestic microwave (KOR-616T). The UV-vis absorption spectra of the aqueous colloid solution were tested by UV-VIS Thermo scientific Nanodrop 8000 spectrophotometer at a resolution of $1 \mathrm{~nm}$ in 220-750 nm wavelength range, the phase purities of synthesized compounds were checked by XRD technique on a Seifert 3003 TT X-ray diffractometer with $\mathrm{Cu} \mathrm{K} \alpha$ radiation with a wavelength of $1.52 \mathrm{~A}^{\circ}$. The FT-IR spectra of Ag NPs and L. cristata leaf extract was inspecting with Thermo Nicolet FT-IR200. The morphological and particle range was determined by TEM which was carried out with a JEOL-JEM-3010 Instrument. SEM, the quantitative elemental study of the NPs were tested by on Oxford instruments Inca Penta FET $\times 3$ EDS, zeta potential, and particle size range was measured by using Horbia Scientific Nano Particle Size Analyzer SZ-100.

\section{Collection of plant materials and preparation of aqueous leaf extract}

L. cristata was confirmed by Department of Botany, Sri Venkateswara University, Tirupati, A.P., India. The fresh, young leaves of L. cristata were collected from Talakona forest near Tirupati, A.P., India. Leaves were washed to remove impurities with tap water and then double distilled water for 3 to 4 times and were dried at room temperature in dust and moisture free condition for 2 days. The fully dried leaves were powdered with sterile electric blender and $10 \mathrm{~g}$ of the fine dry leaves powder was dispersed in $100 \mathrm{~mL}$ of milli-Q-water in $250 \mathrm{~mL}$ round bottom flask and stirred for $45 \mathrm{~min}$ at $60^{\circ} \mathrm{C}$. Then, the solution was carefully filtered by using Whatman no. 1 filter paper and stored at $4^{\circ} \mathrm{C}$ for NPs synthesis.

\section{Biogenic synthesis of Ag NPs}

In order to synthesize Ag NPs, $20 \mathrm{~mL}$ of the aqueous leaf extract was mixed with $80 \mathrm{~mL}$ of $1 \mathrm{mM} \mathrm{AgNO}_{3}$ solution taken in $250 \mathrm{~mL}$ beaker and shake well. Then the reaction mixture was kept under domestic microwave (KOR-616T) and exposed to microwave radiation for $5 \mathrm{~min}$ at a power of $800 \mathrm{~W}$ with a fixed frequency of $2450 \mathrm{MHz}$. After microwave radiation treatment, the resultant solution was cooled to room temperature and stored in dark condition. The change in color wine red to dark brown designates the evolution of colloidal Ag NPs, the colloidal NPs solution was centrifuged at $3500 \mathrm{rpm}$ for $20 \mathrm{~min}$ and the progress of the reaction was monitored with the help of UV-vis absorption spectrophotometer. The formation of Ag NPs was shown in Figure 1.

\section{Antibacterial activity}

The antibacterial activity of the biogenic Ag NPs was tested against Common human pathogenic strains of Escherichia coli, Pseudomonas aeruginosa (Gram -Ve bacteria) and Streptococcus pneumonia (Gram + Ve bacteria) by the agar well diffusion method. The Sterile nutrient agar was poured uniformly on Petri plates and the selected bacterial cultures were spread on the nutrient agar medium by using L-rod. Wells were prepared in the agar plates followed by different concentrations of colloidal Ag NPs $12.5 \mu \mathrm{g} / \mathrm{mL}$ (D1), $25 \mu \mathrm{g} / \mathrm{mL}$ (D2) and $50 \mu \mathrm{g} / \mathrm{mL}$ (D3) 
were added into each one of the wells and Streptomycin $(50 \mu \mathrm{g} /$ $\mathrm{mL}$ ) was used as a standard. The Petri plates were incubated at $37^{\circ} \mathrm{C}$ for overnight ( 24 hours) in aerobic condition. After the incubation period, the zone of inhibition was measured.

\section{RESULTS AND DISCUSSION}

\section{UV-vis analysis}

UV-vis spectroscopy was one of the outstanding techniques to characterize the noble metal NPs. L. cristata leaves extract having biomolecules which can effectively act as reducing agent, actively involved in the synthesis of Ag NPs. The gradual color change from wine red (Leaf extract) to dark brown (colloidal $\mathrm{Ag}$ NPs) due to the reduction of silver ion $\left(\mathrm{Ag}^{+}\right)$and formation of $\mathrm{Ag}$ NPs $\left(\mathrm{Ag}^{0}\right)$. L. cristata leaves extract and biogenic Ag NPs were investigated by UV-vis spectroscopy, the leaf extract did not show any characteristic bands in the visible region while the Ag NPs shows the maximum absorbance band at approximately $430 \mathrm{~nm}$ (Figure 2), which was due to the excitation of surface plasmon resonance (SPR) of Ag NPs. According to Mie's theory, only a single SPR band was expected in the absorption spectra of spherical NPs. UV-vis spectra results show a clear SPR band was observed, which lead to predicting that the Ag NPs are a spherical shape.

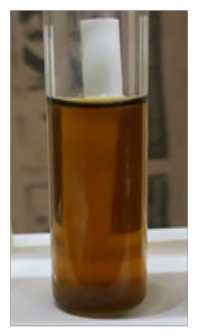

(A)

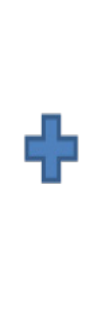

(B)

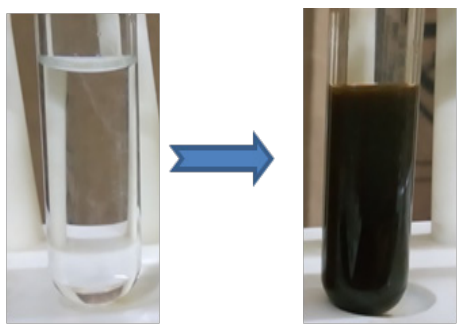

(C)

Fig. 1: A colloidal solution of (A) Lepidagathis cristata Leaves Extract (Wine red color), (B) Silver Nitrate metal ion solution (colorless) and (C) Ag NPs (Dark brown color).

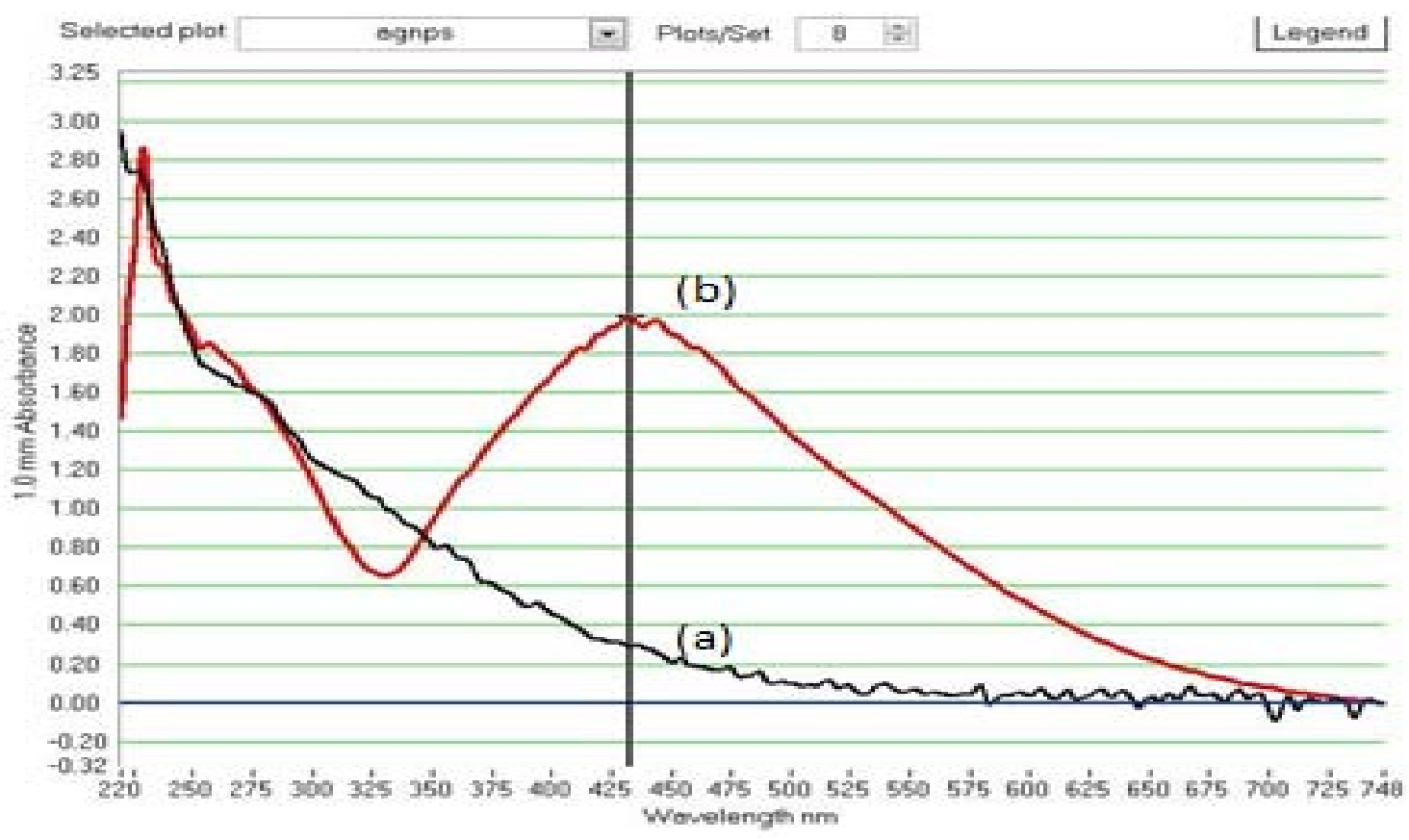

Fig. 2: UV-Visible absorption spectra for (a) Lepidagathis cristata Leaf extract and (b) synthesized Ag NPs.

\section{FT-IR spectrum analysis}

Reports of the FT-IR spectrum of the aqueous leaf extract of $L$. cristata indicates the presence of strong absorption peaks at $3300 \mathrm{~cm}^{-1}$ and $1630 \mathrm{~cm}^{-1}$. The broad signal at $3300 \mathrm{~cm}^{-1}$ corresponds to the presence of secondary amides $(\mathrm{N}-\mathrm{H})$ stretching frequency, a strong signal at $1630 \mathrm{~cm}^{-1}$ corresponds to overlap of the carbonyl group $(\mathrm{C}=\mathrm{O})$ stretching and amide $(-\mathrm{NH})$ bending (Figure 3). The data clearly indicates the presence of an amide 
group which belongs to tryptophan derived alkaloid in L. cristata leaf extract. The amides present in the leaf extract dynamically involved in the reduction of silver ions to metallic Ag NPs. Earlier reports strongly supported that $L$. cristata aqueous leaf extract contains tryptophan derivative alkaloids.

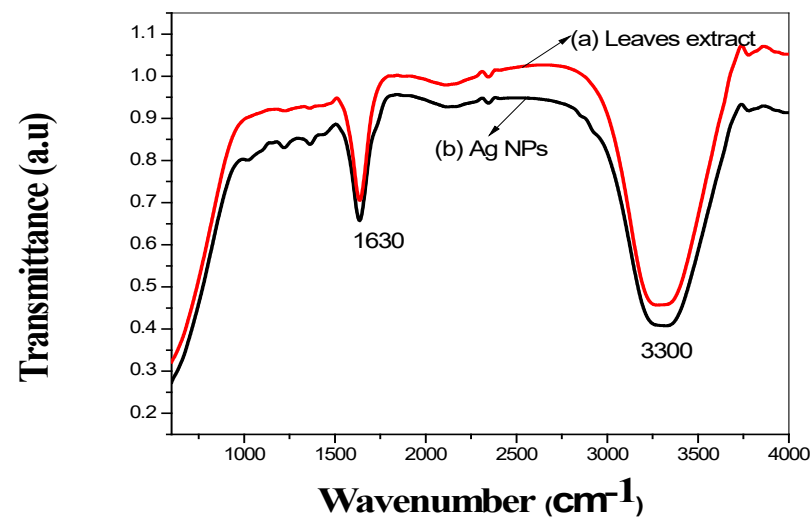

Fig. 3: FT-IR Spectrum of (a) Lepidagathis cristata Leaf extract and (b) Synthesized Ag NPs.

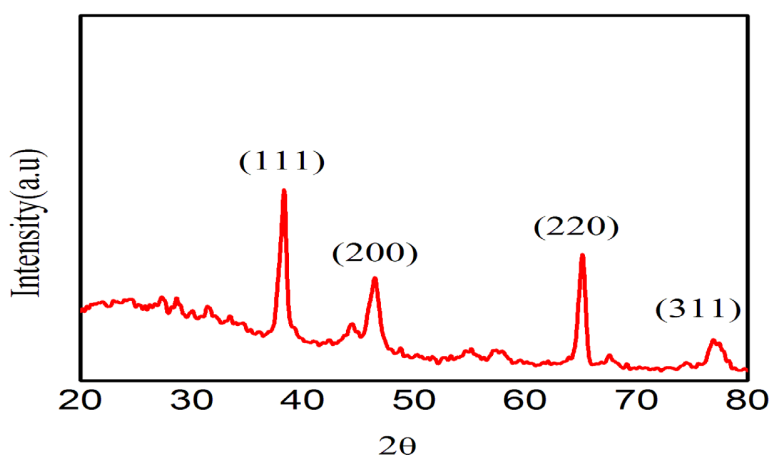

Fig. 4: XRD Pattern of synthesized Ag NPs.

\section{XRD analysis}

The biogenic synthesized stable Ag NPs were examined by XRD which shows good crystanality and face-centered cubic (fcc) structure. Figure 4 shows the power XRD pattern of Ag NPs peaks at $2 \theta$ values of $38.1^{\circ}, 45.8^{\circ}, 64.5^{\circ}, 77.4^{\circ}$ and were indexed at (111), (200), (220), and (311), respectively. The observed diffraction reflections are comparable with the standard values (JCPDS card No. 89-3722). There were no diffraction peaks corresponding to the precursor Ag NPs and byproducts were not observed, which confirms that only metallic Ag NPs was formed rapidly by leaf extract treatment. The width and intensity of (111) plane were relatively higher than the other mentioned planes, which indicates that biogenic Ag NPs are in nano-sized. The average grain/particle size of the Ag NPs formed in the biogenic reduction method was determined using Scherr's formula.

$$
\text { Scherr's formula } \mathrm{D}=0.9 \lambda / \beta \operatorname{Cos} \theta \text {, }
$$

where $\mathrm{D}$ was the average particle size, $\lambda$ was the wavelength of the $\mathrm{X}$-ray, $\beta$ was the line broadening at half maximum intensity of the diffraction peak, and $\theta$ was diffraction angle of the (111) plane of cubic Ag NPs. The measured average particle size of the Ag NPs was to be less than $40 \mathrm{~nm}$.

\section{Morphology, particle size distribution, and zeta potential analysis}

The morphological and particle range was determined by TEM. The image of Ag NPs was spherical in shape (Figure 5). The particles were found to have different sizes ranging from 20 to $50 \mathrm{~nm}$ in diameter and average particle size range as obtained from TEM analysis was found to be $30 \mathrm{~nm}$. TEM images were obtained by JEOL JEM-3010 instrumentation at $200 \mathrm{KV}$. The images clearly revealed the presence of a slight thin layer on the surface of Ag NPs prepared using the leaf extract of L. cristata which may be due to the biogenic organic molecules from the extract which acts as capping and stabilizing agents of the Ag NPs. The SEM image of Ag NPs was shown in Figure 6(a). Morphology of Ag NPs was spherical with fair agglomeration. The EDX result analysis was shown in Figure 6(b), which confirms by the elemental silver. The above results specify that Ag NPs was spherical shape and elemental silver fashioned by a facile manner. zeta potential of Ag NPs were measured by Horbia Scientific Nano Particle Size Analyzer SZ-100, the analysis results showed that the aqueous Ag NPs zeta potential value was $-23.9 \mathrm{mV}$, this elevated negative value indicated the formed Ag NPs have good stability for a long time, the stability of the Ag NPs was very key factor to determine their antibacterial activity (Teeguarden et al., 2007), and particle size range was measured by Horbia SZ-100 with a scattering angle of $90^{\circ}$ at $530 \mathrm{~nm}$ wave length, the results were obtained at room temperature, size distribution was nearly same and the average particle size was $29 \mathrm{~nm}$ in the Aqueous Ag NPs (Polydispersity index value is 0.342 ). The result of zeta potential and particle size range are shown in Figure 7(a) and Figure 7(b).

\section{Antibacterial studies}

The biogenic synthesized Ag NPs with different concentrations viz. $12.5 \mu \mathrm{g} / \mathrm{mL}$ (D1), $25 \mu \mathrm{g} / \mathrm{mL}$ (D2) and 50 $\mu \mathrm{g} / \mathrm{mL}$ (D3) were tested for their antibacterial activity by using Agar well diffusion method. Ag NPs showed a potential antibacterial activity against the test pathogens Escherichia coli, Pseudomonas aeruginosa (Gram -Ve bacteria) and Streptococcus pneumonia (Gram +Ve bacteria). Table 1 and Figure 8 show the zone of inhibition for three different concentrations of biogenic synthesized Ag NPs against the bacterial activity.

The results showed that biogenic synthesized Ag NPs at their lower concentrations inhibited the growth of test pathogens, as a result, clear inhibition zone was observed for all selected pathogens such as E. coli $(9 \pm 0.5 \mathrm{~mm})$, P. aeruginosa $(6 \pm 0.5$ $\mathrm{mm})$ and $S$. pneumonia $(7 \pm 0.5 \mathrm{~mm})$. This was clearly indicated that E. coli was more susceptible to Ag NPs than P. aeruginosa and $S$. pneumonia. Three different concentrations of Ag NPs such as D1, D2, and D3 showed clear various zone of inhibition against the selected bacterial pathogens, these results are compared with to that of relative antibacterial activity of standard antibiotic i.e. Streptomycin (which showed the Max. inhibition zone $23 \pm 0.5$ $\mathrm{mm}, 22 \pm 0.5 \mathrm{~mm}$ and $26 \pm 0.5 \mathrm{~mm}$ for P. aeruginosa, E. coli, and $S$. pneumonia respectively at the concentration of $50 \mu \mathrm{g} / \mathrm{mL}$ ).

The results clearly demonstrated that the zone of bacterial inhibition increases with increase in the concentration 
of biogenic synthesized NPs. D1 and D3 concentrations showed more inhibition zone on E. coli and Streptococcus pneumonia similarly Pseudomonas aerogenosa was also reasonably inhibited. D2 concentration also possesses good inhibition zone on all three bacterial pathogens.
Observations of the present investigation obviously stated that three different concentrations of biogenic synthesized Ag NPs exhibited fine antibacterial activity against selected pathogens in Agar well diffusion method.

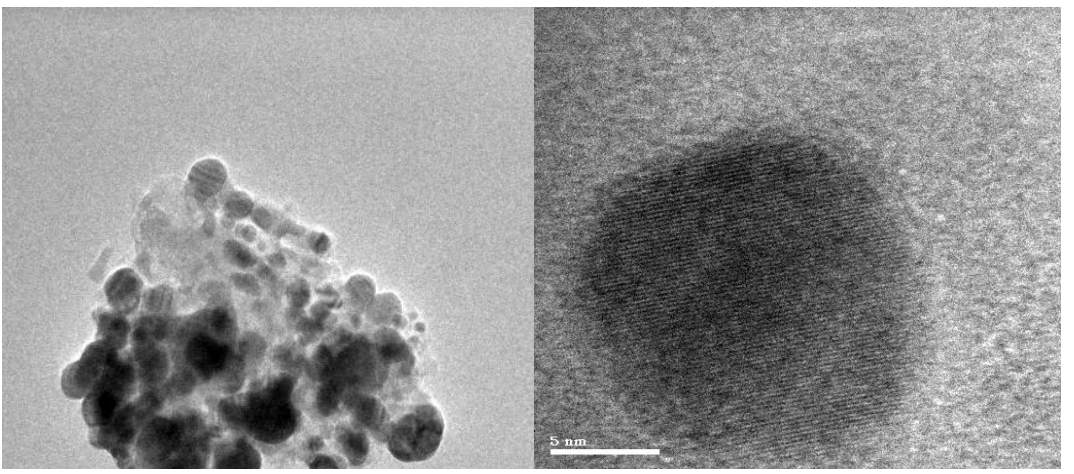

Fig. 5: Transmission electron microscope (TEM) image of synthesized Ag NPs.

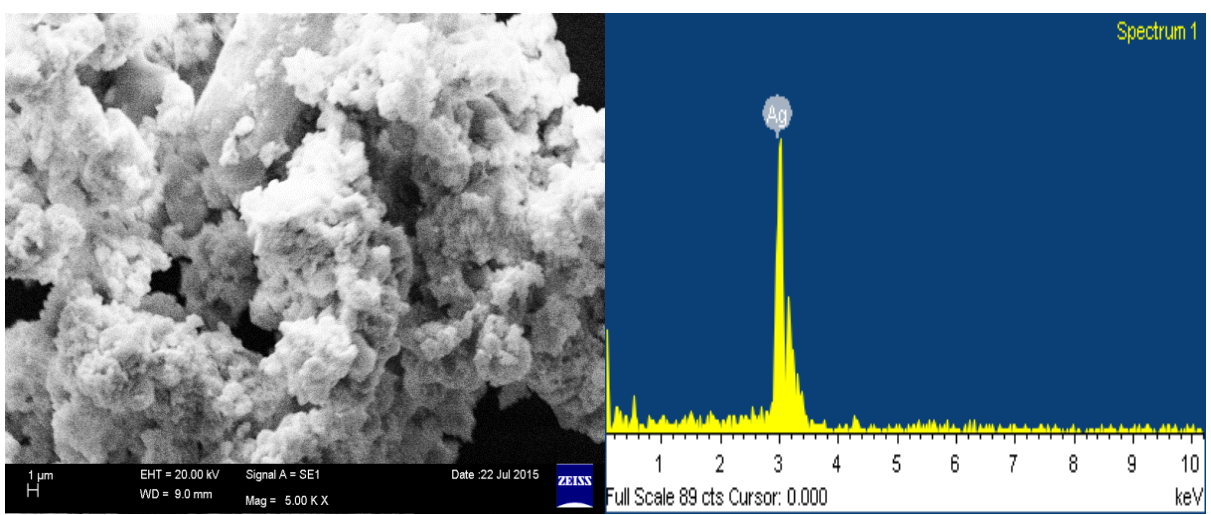

Fig. 6: (a) Scanning electron microscope (SEM). (b) Energy dispersive X-ray spectroscopy (EDX) images of synthesized Ag NPs.
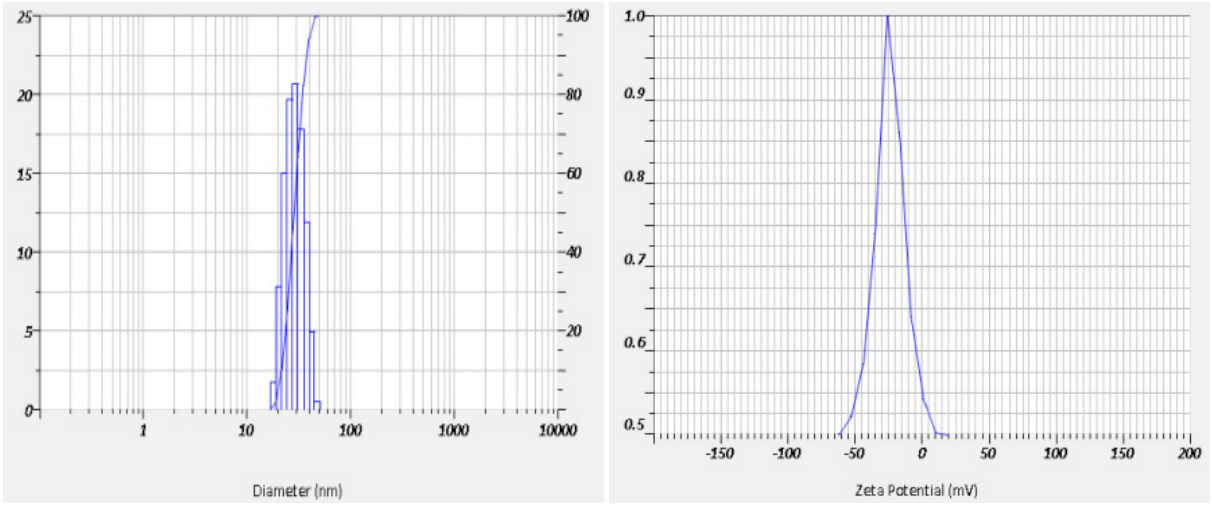

Calculation Results Calculation Results

\begin{tabular}{|c|c|c|c|c|}
\hline Peak No. & S.P.Area Ratio & Mean & S. D. & Mode \\
\hline 1 & 1.00 & $29.0 \mathrm{~nm}$ & $6.1 \mathrm{~nm}$ & $29.0 \mathrm{~nm}$ \\
\hline 2 & --- & $---\mathrm{nm}$ & $---\mathrm{nm}$ & $---\mathrm{nm}$ \\
\hline 3 & --- & $---\mathrm{nm}$ & $--\mathrm{nm}$ & $---\mathrm{nm}$ \\
\hline Total & 1.00 & $29.0 \mathrm{~nm}$ & $6.1 \mathrm{~nm}$ & $29.0 \mathrm{~nm}$ \\
\hline
\end{tabular}

\begin{tabular}{|c|c|c|}
\hline Peak No. & Zeta Potential & Electrophoretic Mobility \\
\hline 1 & $-23.9 \mathrm{mV}$ & $-0.000186 \mathrm{~cm} 2 / \mathrm{Vs}$ \\
\hline 2 & $--\mathrm{mV}$ & $--\mathrm{cm} 2 / \mathrm{Vs}$ \\
\hline 3 & $--\mathrm{mV}$ & $--\mathrm{cm} 2 / \mathrm{Vs}$ \\
\hline
\end{tabular}

Cumulant Operations

Z-Average: $3755.2 \mathrm{~nm}$

PI: 0.342 (Polydispersity index)

Fig. 7: (a) Particle Size Analyzer (PSA. (b) Zeta potential (ZP) images of synthesized Ag NPs. 

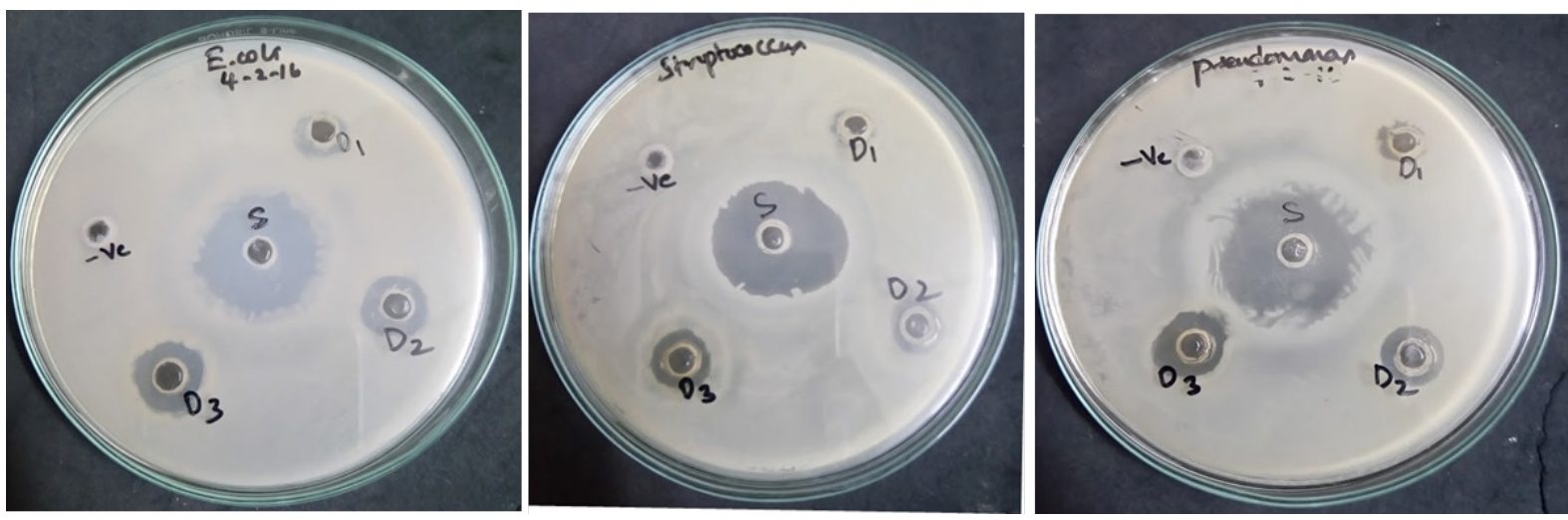

Fig. 8: Anti-bacterial activity of three different concentrations of biogenic synthesized Ag NPs.

Table 1: The variation of the zone of inhibition measured by well diffusion method for different bacteria.

\begin{tabular}{|c|c|c|c|c|c|c|}
\hline \multirow{2}{*}{ S. No. } & \multirow{2}{*}{ Bacterial Strain } & -Ve control & D1 $(12.5 \mu \mathrm{g} / \mathrm{mL}) \pm \mathrm{SD}^{*}$ & $\mathrm{D} 2(25 \mu \mathrm{g} / \mathrm{mL}) \pm \mathrm{SD}^{*}$ & D3 $(50 \mu \mathrm{g} / \mathrm{mL}) \pm \mathrm{SD}^{*}$ & Streptomycin standard $(50 \mu \mathrm{g} / \mathrm{mL}) \pm \mathrm{SD}^{*}$ \\
\hline & & \multicolumn{5}{|c|}{ Zone of bacterial inhibition was expressed in millimeters } \\
\hline & Escherichia coli & 0 & $9 \pm 0.5$ & $13 \pm 0.5$ & $16 \pm 0.5$ & $23 \pm 0.5$ \\
\hline & Pseudomonas aeruginosa & 0 & $6 \pm 0.5$ & $11 \pm 0.5$ & $15 \pm 0.5$ & $22 \pm 0.5$ \\
\hline & Streptococcus pneumoniae & 0 & $7 \pm 0.5$ & $13 \pm 0.5$ & $16 \pm 0.5$ & $26 \pm 0.5$ \\
\hline
\end{tabular}

$*_{ \pm} \mathrm{SD}:$ standard deviation.

Literature suggests that there are several methods by which Ag NPs could be killing the microorganisms, the synthesized Ag NPs was to achieve extensively high antimicrobial activity at low concentration levels and smaller Ag NPs shows good antimicrobial activity than bigger ones. Ag NPs have the capability to attach to sulfur containing proteins in the cell membrane, inside the cell and phosphorus in the nucleic acid (DNA) are likely to be the favorite sites for binding of Ag NPs and then penetrate it, thereby causing structural changes in the cell membrane like permeability of the cell membrane and injure of the cell membrane and death of the cell (Ocsoy et al., 2013; Del Lago et al., 2011; Zhao et al., 2010; McDonnell et al., 1999). The amount of DNA injury within the cell increases with increasing concentration of the Ag NPs this indicates that Ag NPs could damage the DNA effectively and to kill the relevant bacteria (Velusamy et al., 2015).

\section{CONCLUSION}

In summary, we have established that Ag NPs were synthesized from aqueous leaf extract of $L$. cristata in a quick method by using eco-friendly microwave assisted biogenic synthesis. The synthesized Ag NPs UV-vis spectroscopy results tell that NPs absorbance peak was in the visible region, FT-IR results $L$. cristata leaf extract having alkaloids which actively involved in reduction of silver ions to metallic Ag NPs, powder XRD analysis showed that Ag NPs was face-centered cubic structure, agglomerated spherical shape it was confirmed by TEM and the elemental analysis was investigated by EDS. Furthermore, the synthesized AgNPs have potential antimicrobial activity at room temperature.

\section{ACKNOWLEDGMENTS}

The author owes his deep gratitude to Indian Institute of Chemical Technology (IICT) - Hyderabad, Indian Institute
Technology (IIT) - Chennai and DST PURSE - S V University for providing the instrumentation facility and one of the authors S. Himagirish Kumar, was gratifying thanks to University Grants Commission (RFSMS-SRF) for providing the economic support.

\section{CONFLICT OF INTEREST}

The authors declare no conflict of interest.

\section{REFERENCES}

Abou El-Nour KMM, Eftaiha A, Al-Warthan A, Ammar RAA. Synthesis and applications of silver nanoparticles. Arabian J of chem, 2010; 3:135-140.

Abudacker $\mathrm{MN}$, Devi $\mathrm{PK}$. In vitro antifungal potential of bioactive compound oleic acid, 3-(octadecyloxy) propyl ester isolated from Lepidagathis cristata willd. (Acanthaceae) inflorescence. Asian Pac J Trop Med, 2014; 7: S190-S193.

Ahmed MJ, Murtaza G, Mehmood A, Bhatti TM. Green synthesis of silver nanoparticles using leaves extract of Skimmia: Characterization and antibacterial activity. Mater Leet, 2015; 153:10-13.

Ajitha B, Reddy YAK, Rajesh KM, Reddy PS. Sesbania grandiflora leaf extract assisted green synthesis of silver nanoparticles: Antimicrobial activity. Mat Today: Proceeding, 2016; 3:1977-1984.

Ammosova L, Jiang Y, Suvanto M, Tapani AP. Precise micropatterning of silver nanoparticles on plastic substrates. Applied Surface Scie, 2017; 401:353-361.

Banala RR, Nagati VB, Karnati PR. Green synthesis and characterization of Carica papaya leaf extract coated silver nanoparticles through X-ray diffraction, electron microscopy and evaluation of bacterial properties. Saudi J of Biological Sci, 2015; 22:637-644.

Bhat MA, Nayak BK, Nanda A. Evaluation of bacterial activity of biologically synthesized silver nanoparticles from Candida albicans in combination with ciprofloxacin. Mat Today: proceedings, 2015; 2: 43954401.

Bonnia NN, Kamaruddin MS, Nawawi MH, Ratimd S, Azlinae HN, Ali ES. Green biosynthesis of silver nanoparticles using Polygonum hydropiper and study its catalytic degradation of methylene blue. Procedia Chem, 2016; 19:594-602. 
Brunon C, Chadeau E, Oulahal N, Grossiord C, Dubost L, Simon F, Bessueille F, Degraeve P, Leonard D. Antimicrobial finishing of textiles intended for food processing industry by plasma enhanced chemical vapor deposition-physical vapor of $\mathrm{Ag}$-SiOCH composites coated with AlxOy or SiOCH encapsulation layers. Thin Solid Films, 2017; 628:132-141.

Cheera P, Gutha Y, Ponneri V. Biogenic synthesis of $\mathrm{Fe}_{3} \mathrm{O}_{4}$ magnetic nanoparticles using Pisum sativum peels extract and its effect on magnetic and Methyl orange dye degradation studies. J of Mag and Magnetic Materials, 2017; 424:376-381.

Cheera P, Karlapudi S, Narasimha Rao C, Venkateswarlu $\mathrm{P}$, Bahadur I. A highly resourceful magnetically separable magnetic nanoparticles from aqueous peel extract of Bottle gourds for organic dyes degradation. J of Mol Liq, 2017; 243:611-615.

Cheera P, Krishna Murthy P, Hari KR, Sreenivasa RR, Suneetha $\mathrm{V}$, Ponneri V. Bio-inspired green synthesis of $\mathrm{RGO} / \mathrm{Fe}_{3} \mathrm{O}_{4}$ magnetic nanoparticles using Murrayakoenigii leaves extract and its application for removal of $\mathrm{Pb}$ (II) from aqueous solution. Journal of Env Chem Eng, 2017; 5:4374-4380.

Cheera P, Sreenivasulu K, Gangadhara S, Venkateswarlu P. Bio inspired green synthesis of $\mathrm{Ni} / \mathrm{Fe}_{3} \mathrm{O}_{4}$ magnetic nanoparticles using Moringa oleifera leaves extract: A magnetically recoverable catalyst for organic dye degradation in aqueous solution. J of Alloys and Compounds, 2017; 700:252-258.

Cheera Prasad, Karlapudi S, Venkateswarlu P, Bahadur I, Kumar $\mathrm{S}$. Green arbitrated synthesis of $\mathrm{Fe}_{3} \mathrm{O}_{4}$ magnetic nanoparticles with nanorod structure from pomegranate leaves and Congo red dye degradation studies for water treatment. J of Mol Liq, 2017; 240:322-328.

Daniel MC, Astruc D. Gold nanoparticles: assembly, supramolecular chemistry, quantum-size-related properties, and applications toward biology, catalysis, and nanotechnology. Chem Rev, 2004; 104:293346.

Del Lago V, Franca de Oliveira L, De Almeida Goncaleves K, Kobarg J, Borba Cardosa M. Size selective silver nanoparticles: future of biomedical devices with enhanced bacterial properties. J Mater Chem, 2011; 21:12267-12273.

Fereshteh Z, Rojaee R, Sharifnabi A. Effect of different polymers on morphology and particle size of silver nanoparticles synthesized by modified polyol method. Superlattices and Microstruc, 2016; 98:267-275.

Gabriel JS, Gonzaga VAM, Poli AL, Schmitt CC. Photochemical synthesis of synthesis of silver nanoparticles on chitosans/montmorillonite nanocomposite films and antibacterial activity. Carbohydrate Polymers, 2017; 171:202-210.

Galletto P, Brevet PF, Girault HH, Antonie R, Boroyer M. Enhancement of second harmonic response by adsorbates on gold colloids: the effect of aggregation. J Phys Chem B, 1999; 103:8706-8710.

Gulnaz RN, Rezeda RF, Rezeda KM, Lrek RN, Marsil KK, Albina YZ, Vitaliy VY. Electrochemical synthesis of silver nanoparticles in solution. Electrochem Communications, 2015; 50:69-72.

Han HJ, Yu T, Kim W, Im SH. Highly reproducible polyol synthesis for silver nanocubes. Journal of Crystal Growth, 2017; 469:48- 53.

Han M, Gao X, Su JZ, Nie S. Quantum-dot-tagged microbeads for multiplexed optical coding of biomolecules. Nat Biotechnol, 2001; 19:931-635.

Hao SY, Li YH, Hao ZC, Cui GH. Sonochemical synthesis of two nanostructured silver (I) coordination polymers based on semi-rigid bis(benzimidazole) ligands. Ultrasonics sonochem, 2017; 39:636-644.

Huya TQ, Thanha NTH, Thuya NT, Chunga PV, Hung PN, Lec AT, Hanha NTH. Cytotoxicity and antiviral activity of electrochemicalsynthesized silver nanoparticles against poliovirus. J of Virological Methods, 2017; 241:52-57.

Jiang H, Moon S.K, Zhang Z, Pothukuchi S, Wong P.C, Variable frequency microwave synthesis of silver nanoparticles. J Nanopart Res, 2006; 8:117-124.

Jose M, Dhas SAMB, Daisy AD, Das SJ. Synthesis and characterization of nano spheres decorated silver bromide nanorods using a two step chemical reduction route. Optik- Int J Light Electron Opt, 2016; 127:8019-8023
Kim B, Lee J. One-pot photochemical synthesis of silver nanodisks using a conventional metal-halide lamp. Materials Chem and Phycs, 2015; 149-150:678-685.

Kumar V, Yadav SK. Plant mediated synthesis of silver and gold nanoparticles and their applications. J Chem Technol Biotech, 2009; 84:151-157.

Lopez-Esparza J, Espinosa-Cristobal LF, Donohue-Cornejo A, Reyes-Lopez SY. Antimicrobial activity of silver nanoparticles in polycaprolactone nanofibers against Gram-positve and negative bacteria. Ind Eng Chem Res, 2016; 55:1253-12538.

Maier SA, Brongersma ML, Kik PG, Meltzer S, Requicha AAG, Atwater HA. Plasmonics- a route to nanoscale optical devices. Adv Mater 2001; 13:1501-1505.

McDonnell G, Russell AD. Antiseptics and disinfectants: activity action and resistance. Clin Microbiol Rev, 1999; 12:147-179.

Mirkin CA, Letsinger RL, Mucic RC, Storhoff JJ. A DNA-based method for rationally assembling nanoparticles into macroscopic materials. Nature, 1996; 382:607-610.

Morales-Luckie RA, Lopezfuentes-Ruiz AA, Olea-Mejia OF, Liliana AF, Sanchez-Mendieta V, Brostow W, Hinestroza JP. Synthesis of silver nanoparticles using aqueous extracts of Heterotheca inuloides as reducing agent and natural fibers as templates: Agave lechuguilla an silk. Mat Sci and Eng C, 2016; 69:429-436.

Muthu K, Priya S. Green synthesis, characterization and catalytic activity of silver nanoparticles using Cassia auriculate flower extract separated fraction. Spectrochemica Acta Part A: Mol and Bio Spec, 2017; 179:66-72.

Nadagouda NM, Speth T, RS Varma SR, Microwave-assisted green synthesis of silver nanostructure. Acc Chem Res, 2011; 44:469-478.

Nicewarner-Pena SR, Freeman RG, Ress BD, He L, Pena DJ, Walton ID, Cromer R, Keating CD, Natan MJ. Submicrometer metallic barcodes. Science, 2001; 294:137-141.

Ocsoy I, Gulbakan B, Chen T, Zhu G, Chen Z, Sari MM, Peng L, Xiong X, Fang X, Tan W. DNA-guided metal-nanoparticle formation on graphene oxide surface. Adv Mater, 2013; 25:2319-2325.

Ocsoy I, Parent ML, Ocsoy MA, Kunwar S, Chen T, You M, Tan W. Nanotechnology in plant disease management: DNA-directed silver nanoparticles on graphene oxide as an antibacterial agent Xanthomonas perforans. ACS Nano, 2013; 7:8972-8980.

Otari SV, Patil RM, Nadaf NH, Ghosh SJ, Pawar SH. Green synthesis of silver nanoparticles by microorganism using organic pollutant: its antimicrobial and catalytical application. Env Sci Pollut Res, 2014; 21:1503-1513.

Purma AR, Peddireddy VNR, Rao JV. Anti-Inflammatory of Lepidagathis cristata flower extracts. Int J Res Ayu Pharma, 2013; 4:903-905.

Rajeshkumar S. Synthesis of silver nanoparticles using fresh bark of Pongamia piñata and characterization of its antibacterial activity against gram positive and gram negative pathogens. Resource efficient tech, $2016 ; 2: 30-35$

Ravikanth V, Niranjan reddy VL, Ramesh P, Prabhakar Rao T, Diwan PV, Ashok khar, Venkateswarlu Y. An immunosuppressive tryptophan derived alkaloid from Lepidagathis cristata. Photochem, 2001; 58:1263-1266.

Reddy PA, Rao JV. A review of Lepidagathis cristata. Inter Res J of Pharama, 2013; 4: 6-8.

Ruiz-Baltazar ADJ, Reyes-Lopez SY, Larranaga D, Estevez M, Perez R, Green synthesis of silver nanoparticles using a Melissa Officinalis leaf extract with antibacterial properties. Results in Physics, 2017; 7:26392643.

Saha J, Begum A, Mukherjee A, Kumar S. A novel green synthesis of silver nanoparticles and their catalytic action in reduction of methylene blue dye. Sustainable Env Res, 2017; 27:245-250.

Sankar T, Karthiga P, Swarnalatha K, Rajkumar K. Green synthesis of silver nanoparticles using Capsium frutescence and its intensified activity against E.coli. Resource efficient tech, 2017; 3:303308. 
Shankar SS, Rai A, Ahmad A, Sastry MJ. Rapid synthesis of Au, $\mathrm{Ag}$ and bimetallic $\mathrm{Au}$ shell nanoparticles using Neem. J Colloid Interface Sci, 2004; 275:496-502.

Suchomel P, Prucek R, Cerna K, Fargasova A, Panacek A, Gedanken A, Zboril R, Kvitek L. Highly efficient silver particle layers on glass substrate synthesized by the sonochemical method for surface enhanced Raman spectroscopy purposes. Ultrasonics sonochem, 2016; $32: 165-172$

Sun S, Murray CB, Weller D, Folks L, Moser A. Monodisperse $\mathrm{Fe}-\mathrm{Pt}$ nanoparticles and ferromagnetic Fe-Pt nanocrystals super lattices. Science, 2000; 287:1989-1992.

Teeguarden JG, Hinderliter PM, Orr G, Thrall BD, Pounds JG. Particokinetics in vitro: dosimetry consideration for in vitro nanoparticle toxicity assessments. Toxicol Sci, 2007; 95:300-312.

Velusamy P, Das J, Pachaiappan R, Vaseeharan B, Pandian K. Greener approach for synthesis of antibacterial silver nanoparticles using aqueous solution of neem gum (Azadirachta india L.). Ind Crops and Prdc, 2015; 66:103-109.

Victor V, Jerry JW, Abdullah MA, Sambandam A. Sonochemical synthesis of silver nanoparticles anchored reduced grapheme oxide nanosheets for selective and sensitive detection of glutathione. Ultrasonics Sonochem, 2017; 39:363-373.
Vidya H, Swamy BEK, Schell M. One step facile synthesis of silver nanoparticles for the simultaneous electrochemical determination of dopamine and ascorbic acid. J Mol Liq, 2016; 214:298-305.

Welch CM, Compton RG. The use of nanoparticles in electroanalysis: A Review. A Bional Chem, 2006; 384:601-619.

West JL, Halas NJ. Engineered nanomaterials for biophotonics applications: improving sensing, imaging, and therapeutics. Annu Rev Biomed Eng, 2003; 5:285-292.

Xu G, Qiao X, Qiu X, Chen J. Green synthesis of highly pure nano-silver sols-electrolysis. Rare Met Mater Eng, 2013; 42:249-253.

Zhao YY, Tian Y, Cui Y, Liu WW, Ma WS, Jiang XY. Small Molecule- capped gold nanoparticles as potent antibacterial agents that target Gram negative bacteria. J Am Chem Soc, 2010; 132:12349-12356.

How to cite this article:

Kumar SH, Prasad C, Deepa K, Sreenivasulu K, Jyothi NVV. Competitive rapid microwave-assisted biogenic synthesis of spherical silver nanoparticles using an aqueous leaf extract of Lepidagathis cristata: characterization and antimicrobial studies. J App Pharm Sci, 2018; 8(06): 124-131. 